\title{
Prevalence of Enteric Parasites in HIV-Positive Patients with Diarrhoea and Their Correlation with CD4+ T-Lymphocyte Counts
}

\author{
Dr.Saswati Chattopadhyay ${ }^{1}$, Dr. Santanu Pramanik ${ }^{2}$, Dr. Asraful Islam ${ }^{3}$ \\ Dr. Indrajit Gupta ${ }^{4}$, Dr. Paulami Ghosh ${ }^{5}$, Prof (Dr.) Gadadhar Mitra ${ }^{6}$. \\ ${ }^{1}$ Assitant Professor, Department Of Microbiology, Burdwan Medical College, Burdwan, West Bengal,India; \\ ${ }^{2}$ Post Graduate Trainee, Department Of Microbiology, Burdwan Medical College, Burdwan, West \\ Bengal,India; ${ }^{3}$ Post Graduate Trainee, Department Of Microbiology, Burdwan Medical College, \\ Burdwan, West Bengal, India; \\ ${ }^{4}$ Post Graduate Trainee, Department Of Microbiology, Burdwan Medical College, Burdwan West Bengal, \\ India; \\ ${ }^{5}$ Post Graduate Trainee, Department Of Microbiology, Burdwan Medical College, Burdwan, West \\ Bengal,India;, ${ }^{6}$ Prof. \& HOD Department Of Microbiology, Burdwan Medical College, \\ Burdwan, West Bengal, India;
}

\begin{abstract}
:
Background and Objectives: Opportunistic parasitic infections are one of the most serious infections in human immunodeficiency virus (HIV) positive patients. The present study was conducted to determine the prevalence of these coccidian enteric parasites in HIV-positive patients and evaluate their association with their CD4 (CD4+ T lymphocyte) counts.

Materials and Methods: The study was done on 100 HIV-positive patients presenting with diarrhoea and 100 HIV-positive patients without diarrhoea (control) attending the integrated counselling and testing centre (ICTC) of Burdwan Medical College \& Hospital, Burdwan, West Bengal. The CD4+ T-cell count of these patients was also estimated. The stool slides were stained and the parasites were identified by direct microscopy.

Results: Of the 100 diarrhoeic patients, parasites were isolated from 94 samples compared to 11 stool samples from patients without diarrhoea. Cryptosporidium parvum (51\%) was the predominant parasite isolated in HIVpositive patients with diarrhoea followed by Cyclospora (26\%). The maximum parasites were isolated in patients with CD4+ T cell counts below 200 cells/ $\mu l$.

Conclusions: HIV-positive patients with diarrhoea and CD4+ T-cell counts $<200 / \mu l$ has high prevalence of association with intestinal parasitic infections and identification of these parasites may play an important role in treatment to reduce morbidity and mortality in these patients.
\end{abstract}

Keywords: Diarrhoea, CD4+T-cell counts, Coccidian parasites, HIV

\section{Introduction}

Worldwide human immunodeficiency virus (HIV) infection is a serious public health problem and over 40 million people are carrying the infection with deaths in over 20 million people. India, however, is a low prevalence country with an overall HIV prevalence of $0.9 \%$. [1] Opportunistic infections (O.Is) are common complications in patients with HIV infection. ${ }^{[2]}$ Gastrointestinal infections are the commonest infections and diarrhoea is the most common clinical presentation in 30-60\% of HIV patients in developed countries and $90 \%$ in developing countries. ${ }^{[3]}$ The commonest opportunistic parasites are Cryptosporidium parvum, Cyclospora cayetanensis, and Isospora belli ${ }^{[4]}$ which usually spread through contaminated food or water or by direct contact causing nausea, vomiting, weight loss and diarrhoea with abdominal cramps.The degree of immune-suppression is best defined by the CD4+ T-cell count which determines when a HIV patient will develop opportunistic infections. Hence CD4+ T-cell count is an excellent predictor of the risk of developing AIDS among HIV-infected patients. ${ }^{[5]} \mathrm{A}$ decrease in CD4+ T-lymphocyte counts is responsible for the profound immunodeficiencies that lead to various O.Is. ${ }^{[6]}$

A study was conducted in a tetiary care hospital in Eastern India to identify the opportunistic protozoans affecting the HIV patients and to co-relate the presence of these parasites with diarrhoea and CD4+ T-cell counts.

\section{Material \& Methods}

The study was conducted from January 2016 to June 2016 in the integrated counselling and testing centre (ICTC), Department of Microbiology, Burdwan Medical College \& Hospital, Burdwan, West Bengal on 100 HIV-positive patients with diarrhoea and 100 HIV-positive patients without diarrhoea acting as control. Their stool samples were collected in labeled, leakproof, clean sterile plastic containers. The consistency of 
stool samples was noted. A direct wet mount of stool in normal saline was prepared and examined for the presence of motile intestinal parasites and trophozoites under light microscope. Lugol's iodine staining was used to detect cysts of intestinal parasites. The modified acid fast staining technique was used for coccidian parasites (Cryptosporidium, Cyclospora, and Isospora) after concentration of the stool by the formol-ethyl acetate technique.

The CD4+ T-cell count of the patients were also analysed when their stool samples were collected.

\section{Results}

Of the 200 patients, 106 (53\%) were males in the age group of 31-40 years and 94 (47\%) were females. Parasitic infections were detected in $94 \%$ of the stool samples of HIV-positive diarrhoea patients and in $11 \%$ of HIV-positive patients without diarrhoea (controls).

Cryptosporidium was the commonest parasite, isolated in 51/100 HIV-positive diarrhoea patients and in 8/100 HIV-positive patients without diarrhoea. Isospora and Cyclospora were the other isolated parasites. [TABLE 1]

Table 1: Enteric parasites detected from HIV patients with and without diarrhoea

\begin{tabular}{|l|l|l|l|l|}
\hline Parasites & $\begin{array}{l}\text { No. of Parasites with } \\
\text { diarrhoae N=100 }\end{array}$ & $\begin{array}{l}\text { No. of Parasites without } \\
\text { diarrhoae N=100 (Controls) }\end{array}$ & $\%$ \\
\hline Cryptosporidium & 51 & 51 & 8 & 8 \\
\hline Isospora & 17 & 17 & 0 & 0 \\
\hline Cyclospora & 26 & 26 & 3 & 3 \\
\hline Total & 94 & 94 & 11 & 11 \\
\hline
\end{tabular}

Table 2: Enteric parasite and $\mathrm{CD}_{4}+\mathrm{T}$ cell count association

\begin{tabular}{|l|l|l|l|l|}
\hline Parasites isolated & $\begin{array}{l}\mathrm{CD}_{4}+\mathrm{T} \text { cell count }<200 \\
\text { cells/ml }\end{array}$ & $\begin{array}{l}\mathrm{CD}_{4}+\mathrm{T} \text { cell count } \\
200-500 \text { cells/ml }\end{array}$ & $\begin{array}{l}\mathrm{CD}_{4}+\mathrm{T} \text { cell count }>500 \\
\text { cells/ml }\end{array}$ & Total \\
\hline Cryptosporidium & 36 & 15 & 0 & 51 \\
\hline Isospora & 11 & 6 & 0 & 17 \\
\hline Cyclospora & 16 & 10 & 0 & 26 \\
\hline Total & 63 & 31 & 0 & 94 \\
\hline
\end{tabular}

Of all the patients, 36 with the CD4+ $\mathrm{T}$ cells count $<200$ cells/ $\mu \mathrm{l}$ showed the presence of Cryptosporidium while only 15 patients with CD4+ T-cell count in the range of $200-500$ cells $/ \mu \mathrm{l}$ had Cryptosporidium.[TABLE 2] But patients with CD4+ T-cell counts $>500$ cells $/ \mu$ l had negative stool findings. The presence of opportunistic parasites in the stool of HIV patients with diarrhoea thus was found to be inversely proportional to the CD4+ T-cell counts i.e. the lower the CD4 counts the more was the presence of parasites in these patients.

\section{Discussion}

In our study we analysed the prevalence of the common enteric opportunistic intestinal parasites in HIV-positive patients with and without diarrhoea as diarrhoea is an important manifestation. Enteric parasites were detected in $94 \%$ of HIV-infected patients with diarrhoea and $11 \%$ in HIV-positive patients without diarrhoea similar to the study in South India by N. Vyas et al which reported a prevalence ranging from $30 \%$ to $60 \%$ in diarrhoeic HIV-positive patients. [7] Cryptosporidium was the predominant (59/200 i.e. $29.5 \%$ ) enteric parasite in our study of which 51/100 i.e. $51 \%$ was in HIV patients with diarrhoea similar to the study by N. Vyas et al ${ }^{[7]}$ who reported Cryptosporidium in 19\% HIV-positive diarrhea patients. This difference can be attributed to difference in general hygiene and geographicallocation. ${ }^{[7]}$ SS Kumar et al reported Isospora to be the commonest parasite in stool samples of HIVpositive diarrhea patients but we could isolate Isospora only in 17/100 (17\%) of diarrhoeic HIV-positive patients. ${ }^{[8]}$ In a study done in Varanasi ${ }^{[9]}$, Cyclospora was isolated from stools of $24 \%$ HIV-positive diarrhoea patients which correlates well with our study, Cyclospora in $(26 / 100) 26 \%$ of HIV-positive diarrhoea patients. But SS Kumar et al study done in South India reported Cyclospora in only $4.9 \%$ of HIV positive diarrhoea patients. This difference can be explained by geographic variations, living conditions of the patients, and to the prophylacticdrugsusedinthesepatients.

Our study showed the relationship between the CD4+ T cell counts and the presence of opportunistic parasites in stool samples of HIV-positive The maximum isolation of the enteric parasites (63) was at CD4+ Tcell counts $<200 / \mu \mathrm{l}$. Thus, the lower the CD4+ T-cell counts $(<200$ cells $/ \mu \mathrm{l})$ more are chances of isolation of these parasites in stool samples. ${ }^{[10]}$ 


\section{Conclusion}

The high prevalence of intestinal parasitic infections in HIV-positive patients warrants the need of intervention to avoid their consequences. Infection of Cryptosporidium, Isospora, and Cyclospora, was significantly higher in HIV-positive subjects with diarrhoea, particular in those with lower CD4+ T-cell counts and hence their screening is essential for early diagnosis and treatment.

\section{References}

[1]. Wiwanitkit V. Intestinal parasitic infections in Thai HIV-infected patients with different immunity status. BMC Gastroenterol 2001;1:3.

[2]. Janoff EN, Smith PD. Perspectives on gastrointestinal infections in AIDS. Gastroenterol Clin North Am 1988; 17:451-63

[3]. Framm SR, Soave R. Agents of diarrhoea. Med Clin North Am 1997; 81:427-47.

[4]. Mitra AK, Hernandez CD, Hernandez CA, Siddiq Z. Management of diarrhoea in HIV-infected patients. Int J STD AIDS 2001; 12:630-9.

[5]. Talib VH, Khurana SK, Pandey J, Verma SK. Current concepts: Tuberculosis and HIV infection. Indian J Pathol Microbiol 1993; 36:503-11.

[6]. Stein DS, Korvick JA, Vermund SH. CD4+ lymphocyte cell enumeration for prediction of clinical course of human immunodeficiency virus disease: A review. J Infect Dis 1992; 165:352-63.

[7]. Vyas N, Pathan N, Aziz A. Enteric pathogens in HIV-positive patients with diarrhoea and their correlation with CD4+ Tlymphocyte counts. Trop Parasitol 2012; 2:29-34

[8]. Kumar SS, Ananthan S, Saravanan S. Role of coccidian parasites in causation of diarrhoea in HIV infected patients in Chennai. Indian J Med Res 2002; 116:85-9.

[9]. Tuli L, Gulati AK, Sundar S, Mohapatra TM. Correlation between CD4 counts of HIV patients and enteric protozoan in different seasons - an experience of a tertiary care hospital in Varanasi (India). BMC Gastroenterol 2008; 8:36.

[10]. Adamu H, Petros B. Intestinal protozoa infections among HIV positive persons with and without antiretroviral treatment (ART) in selected ART centers in Adama, Afar and Dire -Dawa, Ethiopia. Ethiop J Health Dev 2009; 23:133-40. 